\title{
PERLINDUNGAN HUKUM BAGI PEMILIK E-MONEY YANG DITERBITKAN OLEH BANK DALAM TRANSASKSI NON TUNAI
}

Oleh

Ni Desak Made Eri Susanti*

Ida Bagus Putra Atmadja**

A.A. Sagung Wiratni Darmadi***

\author{
Program Kekhususan Hukum Bisnis, Fakultas Hukum \\ Universitas Udayana
}

\begin{abstract}
ABSTRAK
Penggunaan uang elektronik (e-money) mempermudah dalam bertransaksi namun juga dapat menimbulkan kerugian bagi pemilik apabila e-money tersebut hilang atau dicuri. Transaksi menggunakan e-money dapat dilakukan tanpa melalui proses otorisasi seperti PIN (Personal Identification Number) sehingga e-money dapat digunakan dengan mudah oleh orang lain yang tidak berhak. Dalam peraturan Bank Indonesia Nomor 20/6/PBI/2018 telah dicantumkan pengaturan terkait penggantian kerugian finansial namun belum diatur secara jelas dan terperinci sehingga ketidakjelasan peraturan ini menimbulkan interpretasi yang berbeda-beda antar lembaga yang satu dengan yang lainnya. Tujuan tulisan ini adalah untuk mengetahui pengaturan hukum bagi pemilik uang elektronik apabila terjadi kerugian pada kartu e-money dan untuk mengetahui tanggung jawab bank sebagai penyelenggara kegiatan alat pembayaran non tunai atas kerugian yang dialami oleh pemilik kartu e-money. Metode penelitian yang digunakan dalam tulisan ini yaitu metode penelitian hukum normatif. Hasil studi menunjukkan bahwa penggantian kerugian terhadap e-money hanya dapat dilakukan apabila terjadi kerusakan dari penerbit. Bank tidak bertanggung jawab atas kerugian pemilik e-money yang disebabkan karena kelalaian pengguna yang mana peraturan ini melanggar prinsip perlindungan konsumen.
\end{abstract}

*Penulis pertama Ni Desak Made Eri Susanti adalah Mahasiswi Fakultas Hukum Unversitas Udayana.

**Penulis kedua Ida Bagus Putra Atmadja adalah dosen Fakultas Hukum Universitas Udayana.

***Penulis ketiga A.A. Sagung Wiratni Darmadi adalah dosen Fakultas Hukum Universitas Udayana. 


\title{
Kata kunci: Peraturan Bank Indonesia, Kerugian, Uang Elektronik (e-money).
}

\begin{abstract}
Using the non cash payments of electronic money (e-money) can facilitates transactions but can also cause losses to the owner if the $e$ money is lost or stolen. Transactions using e-money can be done without going through an authorization process such as a PIN (Personal Identification Number) therefore that e-money can be used easily by other unauthorized people. Indonesian Bank Regulation Number 20/6 / $P B I / 2018$ has included regulations relating to financial compensation but has not been clearly and detailed yet, so that the unclear regulations give rise to different interpretations between institutions. The purpose of this paper is to find out the legal arrangements for owners of electronic money in the event of a loss on e-money cards and to find out the bank's responsibility as an organizer of non-cash payment instruments for losses suffered by e-money card owners. The research method used in this paper is the normative legal research method. The study shows that compensation for e-money can only be done if there is damage from the issuer. The bank is not responsible for the loss of e-money owners due to user negligence which this regulation violates the principle of consumer protection.
\end{abstract}

Keywords: Bank Indonesia Regulations, e-money, losses.

\section{PENDAhUluan}

\subsection{Latar Belakang}

Dunia perbankan dapat mempengaruhi kegiatan perekonomian di dalam suatu negara, kemajuan suatu bank dalam negara dapat sebagai tolak ukur kemajuan negara tersebut, maka kemajuan suatu negara sejalan dengan tugas dan peran perbankan dalam mengendalikan peranan suatu Negara tertentu. Oleh karena keberadaan dunia perbankan semakin dibutuhkan tidak hanya oleh masyarakat tetapi juga pemerintah maka adanya anggapan bahwa 
dunia perbankan mempunyai hubungan yang erat dengan perkembangan perekonomian dalam suatu Negara. Apabila dalam sistem perbankan suatu Negara sehat maka akan dapat menunjang pembangunan ekonomi, namun kebalikannya apabila apabila sistem perbankan suatu Negara tidak sehat maka dapat berdampak buruk bagi pembangunan dan pertumbuhan ekonomi suatu Negara.

Dalam perkembangan kehidupan perekonomian suatu negara, uang mempunyai peranan yang sangat penting. Pesatnya perkembangan teknologi saat ini mendorong bank sebagai pendukung utama pembanggunan nasional untuk mengembangkan layanannya baik kepada nasabah maupun masyarakat. Dampak dari adanya perkembangan teknologi dan informasi merasuk ke berbagai bidang tanpa terkecuali pada bidang perbankan khususnya dalam sistem pembayaran seperti sistem pembayaran yang berupa elektronik atau non tunai.

Seiring dengan perkembangannya alat pembayaran di Indonesia mengalami perubahan yang sangat pesat seperti alat pembayaran non tunai. Berkaitan dengan pembayaran menggunakan system elektronik atau non tunai tersebut maka Bank Indonesia sebagai salah satu lembaga keuangan mempunyai kepentingan untuk memastikan bahwa sistem pembayaran non tunai tersebut berjalan aman dan efisien pada saat digunakan oleh masyarakat umum. Hal ini penting mengingat pada asas keamanan dan keselamatan konsumen sebagai bagian dari penyelenggaraan perlindunga kepada konsumen disamping perlindungan kepentingan pelaku usaha.

Transaski dengan menggunakan e-money dapat dilakukan tanpa melalui proses otorisasi terlebih dahulu selain itu tansaksi menggunakan e-money tidak ada hubungan dengan rekening nasabah 
pada suatu bank maka dari itu nasabah pengguna e-money tidak perlu menggunakan konfirmasi PIN untuk menggunakan e-money tersebut. ${ }^{1}$

Dalam penggunaannya perlu diperhatikan bahwa e-money merupakan teknologi ciptaan manusia yang mempunyai beberapa kelemahan. Adapun permasalahan yang akan timbul dalam penggunaan e-money terjadi apabila penggunaan e-money dalam melakukan transaksi pembayaran non tunai tersebut disalahgunakan oleh pihak lain yang tidak berwenang yang dapat mengakibatkan kerugian bagi pemilik e-money tersebut.

Untuk mengantisipasi hal tersebut maka Bank Indonesia memiliki pengaturan hukum terkait uang elektronik diatur melalui Peraturan Bank Indonesia Nomor 20/6/PBI/2018 dimana dalam peraturan tersebut telah dicantumkan pengaturan terkait penerapan prinsip perlindungan konsumen diantaranya diatur mengenai mekanisme penggantian kerugian finansial kepada pengguna yang tertera pada Pasal 43 ayat (2) huruf c. Kendati Peraturan Bank Indoneia Nomor 20/6/PBI/2018 tentang Uang Elektronik tersebut telah mencantumkan mengenai mekanisme penggantian kerugian finansial namun belum diatur secara jelas dan terperinci bagaimana mekanisme penggantian tersebut semisal pengguna kehilangan kartu e-money bukan karena kelalaian atau kesalahannya sendiri melainkan adanya keadaan tidak terduga seperti pencurian atau perampokan. Ketidakjelasan peraturan dan tidak terperincinya peraturan ini menimbulkan interpretasi yang berbeda-beda antar lembaga yang satu dengan yang lainnya baik lembaga bank maupun lembaga non bank.

${ }^{1}$ Anita Candrawati, 2014, "Perlindungan Hukum Terhadap Pemegang Kartu E-Money Sebagai Alat Pembayaran dalam Transaksi Komersial" Jurnal Hukum. Nomor 3 Tahun I, Maret 2014, h.3. 
Berdasarkan uraian-uraian tersebut di atas maka diperlukan suatu perlindungan hukum terhadap pemilik e-money sebagai konsumen, mengingat demikian kompleksnya permasalahan yang menyangkut perlindungan hukum terhadap pemilik e-money, mengingat pada era sekarang ini dimana perdagangan dan transaksi semakin global.

\subsection{Tujuan Penulisan}

Adapun tujuaan dari penulisan ini adalah untuk mengetatahui bagaimana perlindungan hukum bagi pemilik uang elektronik (emoney) yang diterbitkan oleh bank dalam melakukan transaksi non tunai.

\section{ISI MAKALAH}

\subsection{Metode Penelitan}

Penelitian ukum merupakan suatu proses yang ditempuh untuk menemukan aturan-aturan hukum, doktrin-doktrin hukum untuk dapat menjawab isu-isu hukum yang ada. ${ }^{2}$ Pada tulisan ini penulis menggunakan metode penelitian normatif sebagai upaya penyelesaian masalah dari isu hukum dalam tulisan ini. Penelitian ini akan mengkaji terkait dengan norma-norma atau peraturang perundangundangan yang mengatur terkait dengan perlindungan hukum kepada pemberi fidusia atas jaminan fidusia yang dijaminkan oleh penerima fidusia kepada pihak ketiga melalui perjanjian jaminan di Indonesia.

\subsection{Pembahasan}

\subsubsection{Pengaturan Hukum Bagi Pemilik Uang Elektronik Apabila Terjadi Kerugian pada Kartu E- Money.}

2 Peter Mahmud Marzuki, 2010, Penelitian Hukum, Predana Media Group, Jakarta, h. 35. 
Uang merupakan alat pembayaran yang sah dan dapat diterima secara umum, uang merupakan alat pembayaran yang berlaku di wilayah tertentu selain dari pada itu uang dapat juga sebagai alat untuk melakukan pembelian barang dan jasa. Pada masa sekarang ini Bank Indonesia dengan segala upaya berusaha meningkatkan penggunaan alat pembayaran non tunai melalui uang elektronik ( $e$ money). Secara sederhana dapat didefinisikan bahwa uang elektronik adalah suatu alat pembayaran yang disimpan dalam media berupa kartu dalam bentuk elektronik dimana di dalamnya terdapat sejumlah uang. Pada uang elektronik tersebut telah terekam sejumlah nilai uang, maka dapat dikatakan pula bahwa seseorang yang memiliki uang elektronik sama dengan memiliki uang tunai namun perbedaanya terletak pada nilai uang yang telah dikonversikan dalam bentuk data elektronis. Adapun dasar hukum akan penyelenggaraan uang elektronik sebagai salah satu intrumen pembayaran non tunai di wilayah Negara Kesatuan Republik Indonesia diatur dalam peraturan Bank Indonesia Nomor 20/6/PBI/2018 tentang uang elektronik.

Secara umum pengaturan berkaitan dengan perlindungan hakhak konsumen telah diatur dalam Undang-Undang Republik Indonesia Nomor 8 Tahun 1999 tentang Perlindungan Konsumen (selanjutnya disebut UUPK). Pasal 1 angka 2 UUPK menyebutkan bahwa setiap orang yang memakai barang dan/atau jasa yang ada dan tersedia di masyarakat untuk kepentingan sendiri, keluarga masyarakat ataupun makluk hidup lainnya dan tidak untuk diperdagangkan disebut dengan konsumen. Maka dari pada ketentuan pasal tersebut pemilik uang elektronik dapat dikatakan sebagai konsumen pada saat pemilik kartu melakukan transaksi elektronis prabayar dengan penerbit. 
Pasal 1 angka 1 UUPK menyebutkan bahwa perlindungan konsumen merupakan segala upaya untuk menjamin adanya kepastian hukum serta untuk memberikan perlindungan hukum kepada konsumen. Melihat pada ketentuan-ketentuan tersebut maka dapat dikatakan bahwa pemilik atau pemegang e-money berhak mendapatkan perlindungan hukum yang telah diakui dan dijamin perlindungannya oleh Negara.

Perihal kerugian akibat hilangnya uang elektronik tidak diatur secara tegas dalam Peraturan Bank Indonesia Nomor 20/6/PBI/2018. Namun dapat temui dalam Pasal 43 ayat (2) huruf c dicantumkan tentang penerapan prinsip perlindungan konsumen yang mana penerbit diwajibkan untuk memiliki mekanisme penggantian kerugian yang diakibatkan bukan karena kesalahan atau kelalalian pengguna. Penggantian kerugian finansial ini hanya memuat penggantian kerugian karena kesalahan dari penerbit. Namun tidak dijelaskan secara rinci perihal mengenai apa saja jenis kesalahan dan kelalaian pengguna tersebut. Selain itu dalam pasal ini tidak dijelaksan pula dalam hal apa saja konsumen dapat mengklaim penggantian kerugian dari penerbit.

Dalam rangka memberikan perlindungan terhadap pengguna uang elektronik maka Bank Indonesia telah mengeluarkan Peraturan bank Indonesia Nomor 16/1/PBI/2014 tentang Perlindungan Konsumen Jasa Sistem Pembayaran.

Dalam peraturan tersebut diatur mengenai perlindungan yang mencakup perlindungan konsumen dalam kegiatan jasa sistem pembayaran yang salah satunya adalah kegiatan uang elektronik. Selain pada peraturan tersebut dapat ditemukan pula mengenai perlindungan konsumen di dalam UUPK. 
Lebih lanjut Otoritas Jasa Keuangan mengeluarkan peraturan tentang perlindungan Konsumen Sektor Jasa Keuangan Nomor: 1/POJK.07/2013 untuk memberikan paying hukum serta perlindungan kepada konsumen khususnya dalam sector jasa keuangan.

\subsubsection{Tanggung Jawab Bank sebagai Penyelenggara Kegiatan Alat Pembayaran Non Tunai atas Kerugian Yang Dialami Oleh Pemilik Kartu E-Money}

Uang Elektronik (Electronic money) yang dimaksudkan dalam tulisan ini tidak sama dengan alat pembayaran eletronik lainnya meskipun sama-sama berbentuk kartu namun alat pembayaran elektronik berupa e-money berbeda dengan alat pembayaran seperti kartu kredit dan kartu debet. Terdapat dua istilah dalam alat pembayaran elektronis yaitu ada istilah prepaid products dan access products. Pada kartu debet dan kartu kredit merupakan produk elektronis yang bersifat acces products.

Peraturan Bank Indonesia Nomor PBI 14/2/PBI/2012 Tetang Perubahan atas Peraturan Bank Indonesia Nomor 11/11/PBI/2009 tentang Penyelenggaraan Kegiatan Alat Pembayaran Menggunakan Kartu mengatur perihal kartu kredit dan kartu debet. Sementara itu uang elektronik (electronic money) diatur dalam PBI Nomor 20/6/PBI/2018 Tentang Uang Elektronik (Electronic Money).

Penggunaan uang elektronik (e-money) memberikan banyak manfaat bagi kehidupan manusia. Banyak keuntungan yang didapat dengan menggunakan uang elektronik daripada menggunakan uang tunai semisal dalam bertransaksi dalam jumlah yang sedikit. Dalam melakukan transaksi kecil tersebut kita tidak diharuskan menggunkan uang pas dan kita tidak perlu menuggu untuk 
mendapatkan kembalian. Hal yang paling penting dari penggunaan $e$ money adalah konsumen maupun pedagang dapat terhindar dari kesalahan penghitungan uang kembalian.

Apabila ditelaah lebih lanjut menggunakan uang elektronik untuk bertransaksi lebih mudah jika dibandingkan dengan alat pembayaran non tunai lainya. Hal ini dikarenakan dalam transaski menggunakan e-money pemilik tidak memerlukan proses otorisasi tanda tangan ataupun memasukkan kode pengaman seperti PIN pada saat transaksi berlangsung.

Hubungan hukum antara penerbit dan pemegang kartu dalam penggunaan uang elektronik yang sifatnya prabayar maka dapat dikatakan bahwa hubungan hukum tersebut bersifat jual beli. Penerbit menjual sebuah alat penyimpan data berupa kartu prabyar (stored value card) berbeda dengan alat pembayaran menggunakan kartu (AMPK) yang mana hubungan hukum antara pemegang kartu dan penerbit didasari dengan perjanjian simpan menyimpan sesuai dengan Pasal 1 angka (5) UU Perbankan. Dalam transaksi menggunakan uang elektronik, nilai eletronik diperoleh dengan cara menukarkan sejumlah tunai atau melalui pendebetan rekening pada bank penerbit untuk kemudian disimpan dalam bentuk uang elektronik.

Apabila uang elektronik tersebut hilang atau dicuri oleh pihak lain yang bukan merupakan pemiliknya maka penerbit tidak dapat bertanggungjawab karena sifatnya yang prabayar maka sepenuhnya berada dalam penguasaan konsumen begitu pula segala akibat kehilangan maupun pencurian merupakan tanggung jawab penuh pemilik uang elektronik serta tidak dapat dilakukan pemblokiran terhadap kartu e-money tersebut. Sama halnya dengan uang tunai uang elektronik apabila hilang atau dicuri tidak akan dapat dilacak 
atau dilakukan pemblokiran. Hal ini dikarenakan dalam uang elektronik tersebut tidak terdapat alat seperti chip ataupun kode verifikasi, serta tidak bisa dilacak penggunaannya. Selain itu karena $e$ money bersifat offline maka tidak dapat dilakukan pemblokiran. Apabila dalam bertransasksi menggunakan uang elektronik terjadi penyalahgunaan oleh pihak lain yang tidak berhak atas e-money tersebut maka pemilik ataupun pemegang uang elektonik dapat segera melapor kepada bank. Pihak yang tidak berhak tersebut dapat menggunakan e-money tanpa seijin pemilik untuk bertransaksi atau mengubah isi dan data dalam kartu tersebut.

Antara penerbit dan pemegang kartu selaku konsumen dalam hal ini mempunyai hubungan hukum yang bersifat jual beli. Pasal 1457 Kitab Undang-Undang Hukum Perdata (selanjutnya disebut KUHPerdata) menyebutkan bahwa jual beli merupakan suatu persetujuan, dengan mana pihak yang satu mengikatkan dirinya untuk menyerahkan suatu kebendaan, dan pihak yang lain untuk membayar harga yang telah diinginkan. Hak milik barang yang semula dimiliki pihak penjual akan berpindah tangan pada si pembeli apabila sudah terjadi penyerahan secara yuridis sesuai dengan pasal 1459 KUHPerdata. Maka berdasarkan pada prinsip tersebut diatas bank, seluruh pejabat, pengawas dan mitra yang terkait dalam hal ini tidak dapat dimintai pertanggungjawaban oleh pemegang kartu dan oleh pihak manapun atas tuntutan kehilangan kartu oleh pengguna, tuntutan kerusakan kartu yang diakibatkan oleh kecerobohan dari pemegang kartu, tuntutan kerusakan kartu karena tidak menempatkan kartu sesuai dengan petunjuk penggunaan, dan tuntutan atas kerugian sejumlah nilai uang yang ada di dalam kartu akibat dari penggunaan transasksi pembayaran yang tidak benar hal 
ini karena tidak adanya hubungan hukum lagi antara penjual dan pembeli setelah dilakukan transaksi jual beli atau dapat dikatakan putus hukum.

Pasal 1 angka 16 Undang-undang Nomor 7 tahun 1992 tentang perbankan sebagaimana telah diubah dengan Undang-Undang Nomor 10 Tahun 1998 menyebutkan bahwa nasabah adalah orang yang menggunakan jasa bank. Pemegang uang elektronik dapat disebut sebagai nasabah karena menggunakan jasa bank namun sebagai pihak yang menggunakan jasa bank tapi dengan tidak membuka rekening dengan hanya memanfaatkan jasa bank untuk melakukan transaksi keuangan maka hubungan antara bank dengan nasabahnya adalah hubungan yang bersifat keperdataan. Pada hubungan tersebut, nasabah dari bank dapat dikategorikan sebagai konsumen.

Dalam hal terjadinya permasalahan atas pemenuhan hak dan kewajiban pada penyelenggaraan uang elektronik (electronic money), haruslah dapat diselesaikan oleh para pihak. Terdapat dua cara untuk menyelesaikan permasalahan dalam penyelenggaraan uang elektronik yaitu melalui mengadilan dan melalui lembaga di luar pengadilan. Permasalahan yang diselesaikan melalui pengadilan berpedoman pada hukum acara yang mengatur persyaratan-persyaratan yang harus dipenuhi agar sengketa tersebut dapat diajukan dan dapat diketahui upaya-upaya apa saja yang dapat dilakukan. Sedangkan penyelesaian permasalahan diluar pengadilan merupakan penyelesaian permasalahan yang dilakukan berdasarkan kesepakatan dari para pihak. Dalam penyelesaian permasalahan ini didasarkan pada kesepakatan para pihak dan prosedur penyelesaian atas suatu sengketa diserahkan sepenuhnya kepada para pihak yang bermasalah. 
Uang elektronik (e-money) dapat dapat menjadi alat pembayarn non tunai yang memberikan kemudahan dalam transaksi pembayaran, namun dapat pula merugikan pemilik apabila terjadi kehilangan atau pencurian. Penggunaan uang elektronik sepenuhnya menjadi tanggung jawab pemegang uang elektronik karena apabila hilang atau dicuri pemilik tiidak dapat melakukan pemblokiran. Dalam hal terjadinya kelilangan ataupun pencurian bank sebagai penerbit uang elektronik tidak dapat ddimintai pertanggungjawaban atas kerugian yang diderita oleh pengguna uang elektronik tersebut apabila uang elektronik hilang ataupun dicuri maka segala akibat kerugian merupakan tanggung jawab penuh pemegang uang elektronik

\section{PENUTUP}

\subsection{Simpulan}

1. Pengaturan hukum bagi pemilik uang elektronik sebagai alat pembayaran non tunai apabila terjadi kerugian akibat hilangnya kartu e-money sebagaimana diatur dalam Peraturan Bank Indonesia Nomor 20/6/PBI/2018 tersebut belum diatur secara maksimal karena pergantian kerugiaan uang elektronik hanya dapat dilakukan apabila hal tersebut merupakan kerusakan dari penerbit.

2. Bank sebagai penerbit uang elektronik tidak dapat bertanggungjawab atas kerugian yang diderita oleh penguna. Segala akibat kehilangan merupakan tangung jawab penuh pemilik atau pemegang uang elektronik dan pemilik uang elektronik tidak dapat melakukan pemblokiran yang mana dapat dikatakan bahwa peraturan ini melanggar prinsip perlindungan konsumen.

\subsection{Saran}


1. Agar pengaturan hukum terhadap pemilik uang elektronik oleh Bank Indonesia diatur secara lebih jelas dan secara koordinatif dengan berbagai instrumen terkait rangka menjamin adanya kepastian hukum untuk memberikan perlindungan hukum kepada konsumen.

2. Agar penerbit uang elektronik dapat memberikan kepastian mengenai perlindungan hukum apabila uang elektronik hilang ataupun dicuri dengan menambah fitur transaki yaitu mencantumkan chip yang dapat dilacak oleh pengguna uang elektronik untuk mengetahui transaksi yang dilakukan.

\section{BUKU}

Djoni S.Gazali dan Rachadi Usman, 2012, Hukum Perbankan, Sinar Grafika, Jakarta.

Firman Tumantara, 2016, Hukum Perlindungan Konsumen, Setara Press, Malang.

Hermansyah, 2012, Hukum Perbankan Nasional Indonesia Edisi 2, Kencana Pranada Media Group, Jakarta.

Kamir, 2013, Bank dan Lembaga Keuangan Lainnya, Cet.12, Rajawali Pers, Jakarta.

Peter Mahmud Marzuki, 2010, Peneliian Hukum, Predana Media Group, Jakarta.

R.Serfianto et.al., 2012, Untung dengan Kartu Kredit, Kartu ATM-Debit, dan Uang Elektronik, Visi Media, Jakarta.

\section{JURNAL HUKUM}

Anita Candrawati, 2014, "Perlindungan Hukum Terhadap Pemegang Kartu EMoney Sebagai Alat Pembayaran dalam Transaksi Komersial" Jurnal Hukum, Nomor 3 Tahun I. 


\section{PERATURAN PERUNDANG-UNDANGAN}

Undang-undang Dasar Negara Republik Indonesia Tahun 1945.

Kitap Undang-Undang Hukum Perdata.

Undang-Undang Republik Indonesia Nomor 3 Tahun 2004 tentang

Perubahan atas Undang-Undang Republik Indonesia Nomor 23 Tahun 1999 tentang Bank Indonesia.

Peraturan Bank Indonesia Nomor 20/6/PBI/2018 tentang Uang Elektronik (Electronik Money). 